\title{
Economic Integration: The Existence of Cointegration between Brazilian GDP and Mexican GDP
}

\author{
Francisco Américo Cassano ${ }^{1}$, Diego Henrique Cotrim Santos², Carlos Alberto Cuenca Pinto ${ }^{3}$, Caiê Betareli \\ Ciarmoli $^{4}$, Rafael Tsopanoglou Teodoro ${ }^{5}$, Renan Pelegrina ${ }^{6}$
}

${ }^{1}$ Universidade Presbiteriana Mackenzie - e-mail: famcassano@uol.com.br

2Universidade Presbiteriana Mackenzie - e-mail: dh.cotrim@gmail.com

${ }^{3}$ Universidade Presbiteriana Mackenzie - e-mail: cuencappc@gmail.com

${ }^{4}$ Universidade Presbiteriana Mackenzie - e-mail: caie.ciarmoli@live.com

${ }^{5}$ Universidade Presbiteriana Mackenzie - e-mail: rafatso@hotmail.com

${ }^{6}$ Universidade Presbiteriana Mackenzie - e-mail: renanpelegrina@gmail.com

\section{KEYWORDS}

Economic integration;

Economic growth;

Model of Cointegration tests

Received 18.01.2016

Revised 15.02.2016

Accepted 19.04. 2016

ISSN 1980-4431

Double blind review

\section{ABSTRACT}

The process of globalization has expanded international relations and forced companies and countries to formalize a series of strategies to participate competitively in this process. Economic integration is one of these strategies and focuses on uniting efforts of economies with common economic and social interests, by promoting trade, stimulating markets and making the economic relations between these countries more productive and efficient. Considering the hypothesis that from the economic integration there was no relationship between the Brazilian and Mexican GDP, the main focus of this study is to evaluate and register the importance of economic integration for the economic growth of the countries. To analyze the GDP growth of Brazil and Mexico, before and after the integration in their respective blocks, it was applied the Cointegration tests model developed by Engle and Granger. The results obtained allowed to conclude that for the period prior to the integration there was no relationship between the Brazilian and Mexican GDP growth, and, for the period after the GDPs kept relationship between them.

\section{Introduction}

The globalization process has expanded the international relations and forced companies and countries to formalize a number of strategies to participate competitively in this process.

Economic integration is one of these strategies which focus on uniting economies efforts with economic and social interests in common, promoting trade, boosting markets and resulting in more productive and efficient economic relations between the countries. Through bilateral or multilateral agreements, a country may grant benefits to allied country or economic blocs and members only participate in these agreements can take advantage of such benefits.

A country may be part of an economic block for several reasons, including the geographical distance as the Southern Common Market MERCOSUL, North American Free Trade Agreement - NAFTA and the European Union EU. Thus, the establishment of economic blocks is based not only on strengthening the economies, but also in political, social, environmental and cultural interests. 
This document presents, in particular, two similar countries characteristics and how occurred their economic integration strategies, specifically Brazil and Mexico. The following data and information has been obtained in Solow (1956); Engle and Granger (1987); Bielschowsky (2000); Santos (2007).

Brazil adopted a protectionist policy even after its entry into MERCOSUL in 1991, in which the strategy was to prioritize an active industrial policy and tariff and nontariff barriers to protect the internal market for multinational companies. By the year 1990, Brazil was totally closed, outdated and with high inflation rates, its international integration had to gradually occur, and a policy of liberalization, as aggressive as that adopted by Mexico, would have destroyed domestic companies not providing supervision for compete with multinational companies. By allying with emerging countries with little economic potential, generally within MERCOSUL, it was possible to somehow boost the Brazilian economy. Mexico, with the entry into NAFTA, adopted strategy focused on export to get seen in the "first world" and abdicated economic growth planning executed by the state. The United States of North America - USA had strong interest in concluding this treaty (NAFTA), whose political reasons will be addressed throughout this study, and even allying the developed countries, Mexico did not enter the "first world" and not It achieved the expected economic growth, given that the treaty has contributed very little to the annual growth. Considering the hypothesis that from the economic integration Gross Domestic Product GDP, both Brazilian and Mexican, are related to each other, the main focus of this study is to evaluate and record the importance of economic integration for the economic growth of countries. To analyze the growth of GDP in Brazil and Mexico, before and after integration in their respective blocks, and verify that the two economies have common balance in the long term, we used the cointegration model developed by Engle and Granger (1987). This test allows you to analyze the existence of cointegration in longterm relationships between two or more-time series. As an additional component, the logarithmic analysis is used in order to mitigate the possible deviations incurred due to the use of data with time series lower than recommended for analyzes of this kind.

\section{Theoretical Framework}

2.1 Research problem and purpose

Using the hypothesis that from the economic integration Gross Domestic Product - GDP, both Brazilian and Mexican, are related to each other, the following research problem is defined: What is the effect of economic integration in the Brazilian GDP growth and Mexican? In order to provide a complete answer to the problem of research, the study has the following general objective: Identify the behavior of the Brazilian GDP and Mexican GDP before and after the process of economic integration.

To facilitate this goal, the following specific objectives were established:

i. Analyze if there Cointegration in time series of countries, allowing positive or negative assessment of economic integration;

ii. Investigate GDP growth after economic integration, both in Brazil and Mexico; iii. Evaluate the importance of economic integration.

\subsection{Literature Review}

This subsection presents the literature review that forms the theoretical basis of the study, addressing the economic integration as a driving factor of the economic activities of countries with similar economic activities or even complementary; discussing economic growth as an indicator of the benefits provided by economic integration mentioned above; presenting the theory of cointegration, theoretical basis for the methodological characterization of the study.

\subsubsection{Economic Integration}

Balassa (1964), by comparing the economic cooperation with economic integration, referred to this as an act of elimination of protectionist barriers that would complement an international agreement characteristic trade policy of economic cooperation. This initial observation of economic integration has evolved, according Bielschowsky (2000), since it comes from independent states that have the purpose of integrating their economies, obtaining strengthening and providing mutual assistance, generating benefits such as high internal efficiency and protection from external causes. Generally, these states are united by geographic locations and integration agreements should be favorable to do away with

Revista de Negócios, v. 20, n. 3, p. 41-50, July, 2015. 
the barriers that apply to trade in goods and services as part of their liberalization policies for countries outside the integration and, on the other hand, provide the approval of new members to the agreements. According to Carbaugh (2004), economic integration can be understood as a process of removing barriers and restrictions to trade, distinguishing economic integration levels that can be achieved:

i. Free Trade Area: member countries agree to implement a tariff rate of zero import; eliminate tariff and non-tariff barriers, and each member country has its own set of trade restrictions in relations with non-member countries;

ii. Customs Union: two or more countries involved agree on terminate all tariff and non-tariff barriers, with each partner country adopts the same commercial limits to non-member countries. The Common External Tariff - CET concedes a free trade at the perimeter of the customs union, so that all trade restrictions imposed on other countries to be balanced;

iii. Common Market countries involved agree, since the situation of a customs union also release the hand flow of labor and capital. It would be a more advanced stage of integration compared to a free trade area or customs union;

iv. Monetary Union: countries involved decide, from the stage of a common market, the creation of a common currency, unifying the national, social, tax and fiscal policies governed by a supranational institution and thus creating the basis for a "new country". difficult stage to be achieved because, in addition to removing trade barriers, economic sovereignty is transferred to a supranational authority;

v. Economic integration Total: countries involved come to define monetary, fiscal and social common, with an authority that is above the government of each country and in charge of developing and implementing these policies. Corral (2011) considered that economic integration - in the manner presented above and focused on the economic aspects - incorporated other significant aspects: the guarantee to avoid future conflicts; the increase in block trading power in international forums; the ability to increase the competitiveness of production through joint technological efforts. For analytical purposes of this study, in the case of Brazil economic integration through Mercosur, it is characterized as a Customs Union and in the case of Mexico through NAFTA, as a Free Trade Area.

\subsubsection{GDP Growth}

Solow (1956) presented one of the basic models for the analysis of economic growth. First, the models presented addressed two issues:

others?

i. Why some countries are richer than

ii. Why some countries grow faster than others?

According to Solow (1956), the accumulation of physical capital (real estate), the growth of the labor force, the accumulation of human capital and technological change, directly influence economic growth and, on that basis, was concerned to demonstrate that the product per capita (Y) is an increasing function of the ratio between capital and labor. What best explains the rate of production or growth is a function given by the same: $Y=f(K, L, A)$, where $Y$ is the final production of goods; $\mathrm{K}$ is the capital stock (which would be the total physical capital of a person); $\mathrm{L}$ total human capital available and able to produce something; A technology.

Solow (1957) also stated that from 1909 to 1949 , the economic growth of countries occurred largely because of technology, because with the advancement and optimization of processes, activities have become more agile.

Mankiw, Romer and Wiel (1992), based on the study of Solow (1956), retook the statement that the growth of a country can be based on only two variables: savings and population growth. However, the study only provided the direction and the effects that higher or lower level of savings and population growth can bring to the country and did not foresee that the magnitude of such effects, one of the criticized items. For any human capital accumulation rate, the greater the saving or lower population growth, the better the level of income. Also human capital accumulation can be correlated with the savings rate or population growth. Therefore, it would imply the accumulation of human capital of omission, giving a preview of the estimated savings ratio and population growth.

The impact of productivity was studied by Hall and Jones (1999), with the level of productivity, therefore, the higher the level of higher education will be the intensity and efficiency of work, making the most productive

Revista de Negócios, v. 20, n. 3, p. 41-50, July, 2015. 
country in the countries that do not have a high level of education.

More recent studies have included the quality of human capital as a differential factor of uneven growth among countries:

i. Manuelli and Sheshadri (2010) used a theoretical model to estimate the quality and not only quantity in assessing the impacts to economic growth;

ii. Erosa, Koreshkova and Restuccia (2010) conducted a study on human capital, seeking to understand why some countries between the difference in per capita income is twenty times, being demonstrated the importance of human capital quality and its impact on the country's growth.

\subsubsection{Influence of Economic Integration in} the Brazilian GDP Growth.

The Interest in economic integration has grown in recent years due to the benefits that this integration brings to the country to maximize corporate profits and become the most dynamic market. Can be presented as an example, the emergence of MERCOSUR, created in 1991 and composed of Argentina, Brazil, Uruguay, Paraguay and Venezuela (Bielschowsky, 2000).

In Latin America, economic integration interests were influenced by the Economic Commission for Latin America and the Caribbean - ECLAC. The ECLAC ideas brought developments in the integration process in Latin America, helping mainly with respect to its purpose and the present difficulties in the integration process (Bielschowsky, 2000).

Bielschowsky (2000) pointed out some aspects of the influence of economic integration in Latin American economies:

i. The importance of good coordination of macroeconomic policies among countries involved in the integration and as a mismanagement of government policies influence the growth of a country, ECLAC focused on the macroeconomic adjustment of Latin American countries making economic growth the country happened to gradually;

ii. The thought "CEPAL" considered the import substitution as an important factor in the feasibility of industrialization, i.e., replace imported by domestic production was the key issue for the country to develop the industry, and thus could increase exports and consequently economically;

iii. The process of regional economic integration, with the creation of a common market was the answer to economic growth through import substitution. The market liberalization process has a resistance of interest groups, who saw the process as a threat to the internal market. So it was important that occurred a productive restructuring so that the domestic industry was able to compete with foreign firms. Economic integration still had a very strong connection with the country's economic growth, with the aim of that leverage the comparative advantages and economies of scale with the expansion of the market, bringing economic growth for the countries involved.

This set of mind Bielschowsky (2000) was brought in part by Gremaud, Vasconcellos and Toneto Jr. (2005), which pointed out the lack of coordination of macroeconomic policies and the difficulties that unilateral measures cause as big issue to be solved by the MERCOSUL.

To Krugman and Obsfeld (2005), the substitution of importation is not necessarily the best police to be adopted, because it does not match the comparative advantage (Model Ricardian), and is not always that we can find high potential industries with high earnings over labor. Another reasonable fact is that with the high Taxes the Government makes the importation expensive, directing the demand to the local market, making the local production increase.

Veiga (2007), in the other hand, analyzed that in 2002 the Brazilian exportation had a big increment, one of the reasons that put the economic integration is question, and how could it really help the country to grow.

To Sarquis (2001), the economic growth is very important to the emerging countries, because this helps the economic, so the country has more jobs, per capita income. Brazil good performances during five years, 2004 until 2008, when the GDP was increasing every year, during that time the GDP grew $4,8 \%$ or $3 \%$ on the per capita income. After the economic crises of 2008, when the Brazilian GDP started to slow down, in 2010 it picked up a little increasing 7,5\% and 2,7 in 2011.

Some other consequences of economic integration with the growth of the Brazilian economy were observed by Sarquis (2011) as inhibiting factors for economic growth:

Revista de Negócios, v. 20, n. 3, p. 41-50, July, 2015. 
i. Brazil in 2009, had a fall in the volume of imported and exported around $10 \%$ and $11 \%$, respectively, with a smaller decline than the developed countries;

ii. In 2010 there was a major recovery, with an increasing volume of $11.5 \%$, but lower than developed countries (14.5\%);

iii. The volume imported in 2011, grew $36 \%$ in Brazil, while the world average was $12.5 \%$ and $13.5 \%$ for developed countries.

\subsubsection{Influence of Economic Integration in the Mexican GDP Growth}

The literature on Mexico's integration process is not abundant, especially with the approach taken in this study, and thus, was used to the full the work of Santos (2007).

In the 1980s, with the Mexican debt crisis, governments began the process of economic liberalization, from a strategy focused on exports so as to achieve economic growth. During the government of Miguel de la Madrid (1982-1988) in 1985, Mexico joined the General Agreement on Tariffs and Trade - GATT and, therefore, has scheduled a policy of reduction of tariffs and free trade agreements, getting management geared towards trade liberalization factors. When they started the negotiations of NAFTA, Mexico was already able to enter the agreement and, accordingly, effectively joined on 1 January 1994, since it was already in the market liberalization process. Mexico abandoned the protectionist policy, before prevailing in the country, and became a US ally, which was seen by Mexicans as the first step to become a developed country. Thus, Mexico hoped to attract targeted foreign investors to the country's structure and bring greater technological base, and thereby increase exports and become the most dynamic market. More than $65 \%$ of Mexico's foreign trade is for the US (SANTOS, 2007).

The entry of Mexico in NAFTA did not represent to the US only to maximize corporate profits, but rather geo-economics interests in Mexican natural resources in order to ensure safer conditions for investors and intellectual property, ensure power supply with low cost, and with the help Mexico combat illegal immigration and drug trafficking (SANTOS, 2007).

The strategy adopted by Mexico to attract foreign investment, thus boosting exports and thereby get economic growth, proved to be a failure in growth rates and the country's social indicators. It is fact that increase of the foreigner investment and labor specialization occurred after the treaty did not bring to Mexico the expected growth or helped to take the country to the first world (SANTOS, 2007).

The annual rate of growth of the Mexican GDP, after the treaty was $2.5 \%$, lower than the $2.3 \%$ of the 1984-2003 period. The impact of NAFTA was not relevant to the GDP growth, something around $0.5 \%$ per year, while the minimum wage decreased by $21.34 \%$ compared to 1994 (SANTOS, 2007).

\subsection{Cointegration test Engle and Granger}

In econometrics, an important issue is the need of short-term dynamic integration with longterm balances. The analysis of the short-term dynamics is often accomplished by eliminating the variables trends, often by differentiation. However, this procedure does not consider potentially important information about the longterm relationships. The Cointegration theory developed by Engle and Granger (1987), devoted to the question of integrating short-term dynamics with long-term balances (MADDALA, 2003).

According to Gujarati (2006), Cointegration tests showed great importance in the field of economic and econometric studies. Considered that the cointegration suggests the combination of two or more-time series, this combination may be stationary even though the individual nonstationary series. Through these tests can check for long-term balance between economic variables.

The study Engle and Granger (1987) noted that, from the economic point of view, two or more variables are cointegrated if they are jointly move over time and their differences are stable even when each particular series contain a stochastic trend and is therefore not stationary. The most economic series is presented as nonstationary, since share common stochastic trends.

If two or more series move along synchronously time their movements have the same length. Thus, in the same order they are cointegrated, i.e., is I (d), where $d$ is the order of integration. If these sets are not individually stationary and follow a stochastic trend, a linear combination between them is usually stationary, because the common trend is removed. The linear combination makes the stochastic trends of the

Revista de Negócios, v. 20, n. 3, p. 41-50, July, 2015. 
two series to cancel out each other. In other words, two or more series are cointegrated if not stationary, but is formed by a combination thereof is integrated into zero-order, i.e. I (0) (GUJARATI, 2006).

Engle and Granger (1987) formulated a test to check for Cointegration between two or more variables. This test, following the unit root verification procedures developed by Dickey and Fuller in 1976 and 1981, is to estimate the first difference of waste, $\Delta \mathrm{u} \_\mathrm{t}$ as a function of these values with a delay $\left(\mathrm{u}_{-}(\mathrm{t}-1)\right)$ and past values for successive differences $\Delta \mathrm{u} \_\mathrm{t}$ if there is suspicion of auto serial correlation.

\section{Methodology}

The research method is descriptive quantitative, with the following hypotheses to be tested:

$\mathrm{Hi}=$ from the Economic Integration was no relationship between the Brazilian GDP and Mexican GDP;

Ho $=$ from the Economic Integration there was no relationship between the Brazilian GDP and the Mexican GDP.

Therefore, for this study, they were considered as independent variables Economic Integration and the dependent variable to GDP growth.

All the information of this study was obtained in official publications in Brazil and Mexico, supplemented in database international institutions in Brazil and Mexico. The series consist of the GDPs of Brazil and Mexico (in current US \$) were obtained through the site of the International Monetary Fund - IMF. For quantification of the data it was used cointegration method, developed by Engle and Granger em1987.

In order to better provide analytical capacity, we opted for the series of data from 1980 to the two countries, regardless of the time of integration of the blocks. For graphical presentation, data were organized into four series, considering the GDPs of Brazil and Mexico before and after the economic integration:

i. GDP 1980-1989 Brazil;

ii. GDP of Mexico from 1980 to 1989;

iii. GDP 1994-2013 Brazil;
2013.

iv. GDP of Mexico from 1994 to

From the processing of data and the application of Cointegration test of Engle and Granger (1987), the following figures were generated:

Figure 1 - Brazil and México GDPs before and after economic integration - US $\$$ billion

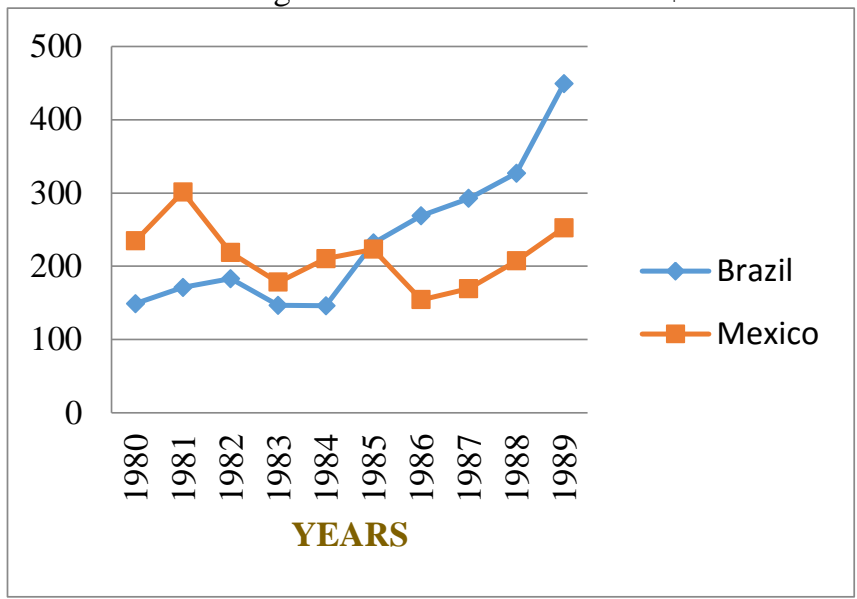

Source: Prepared by the authors, based on secondary data.

Figure 2 - Brazil and México GDPs after economic integration - US\$ billion

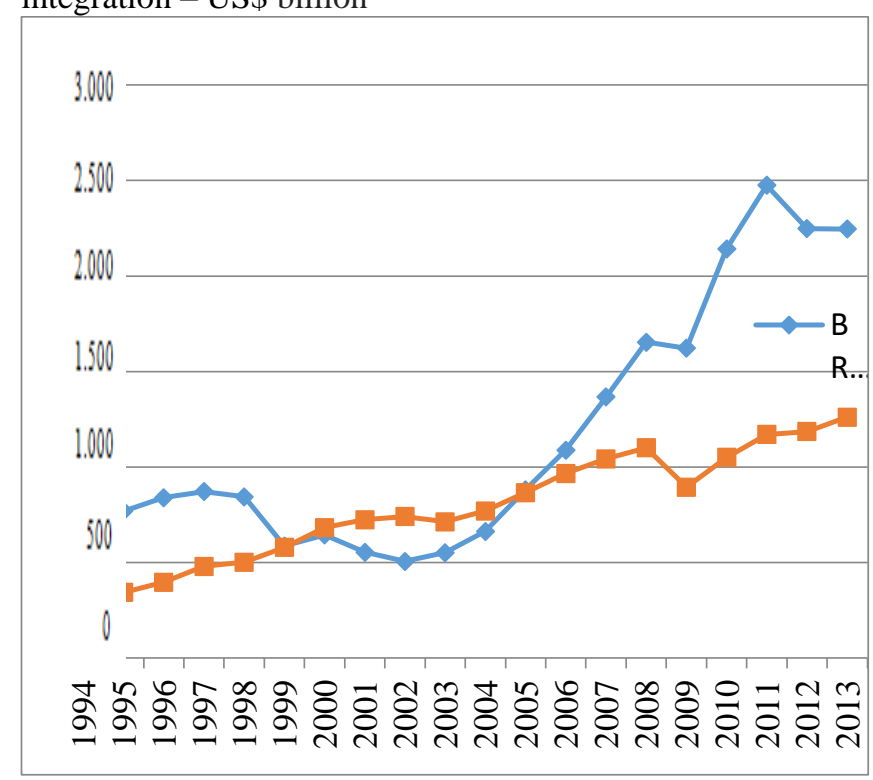

Source: Prepared by the authors, based on secondary data.

\section{Data Analyses}

Through Figure 1 and Figure 2, it is clear that the data series are presented as non-stationary as it does not develop, over time, around a constant mean and are not invariant with respect to time, as Gujarati (2006).

As analytical reference and better understanding, in Figure 3 contains the characteristic behavior patterns of stationary and

Revista de Negócios, v. 20, n. 3, p. 41-50, July, 2015. 
non-stationary series:

Figure 3 - Stacionaries and No Stacionaries series

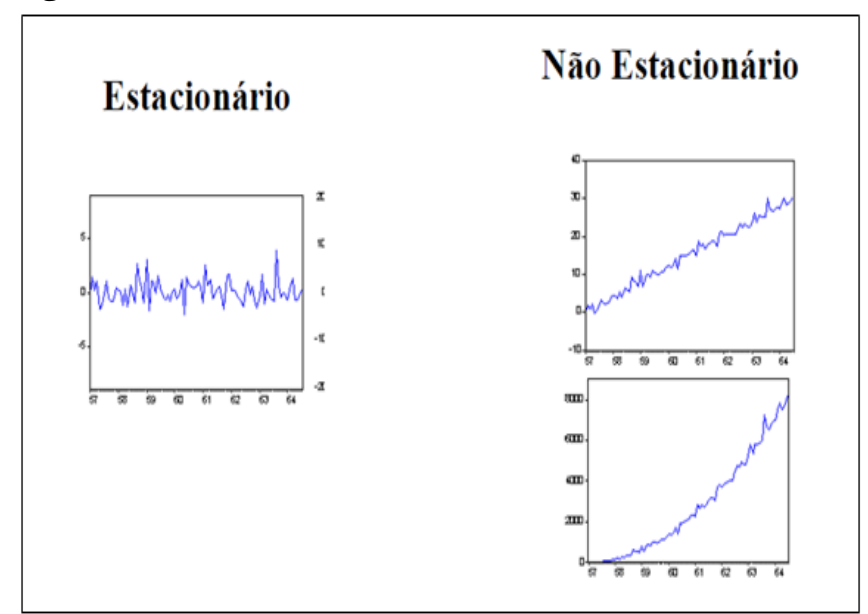

Source: Gujarati (2006)

In cases of application of regression on nonstationary time series on other non-stationary series, if there is no evidence of cointegration between them, it is clear that the result is a spurious regression and therefore there is no relationship of cause and effect between the variables (GUJARATI, 2006).

Figure 4 shows the two series together and their behavior, and although deem evidence of no stationary demonstrate present Cointegration property since the two series show signs of "run together", especially during the years preceding the 2008 crisis.

Figure 4 - Brazil and México GDPs before and after economic integration

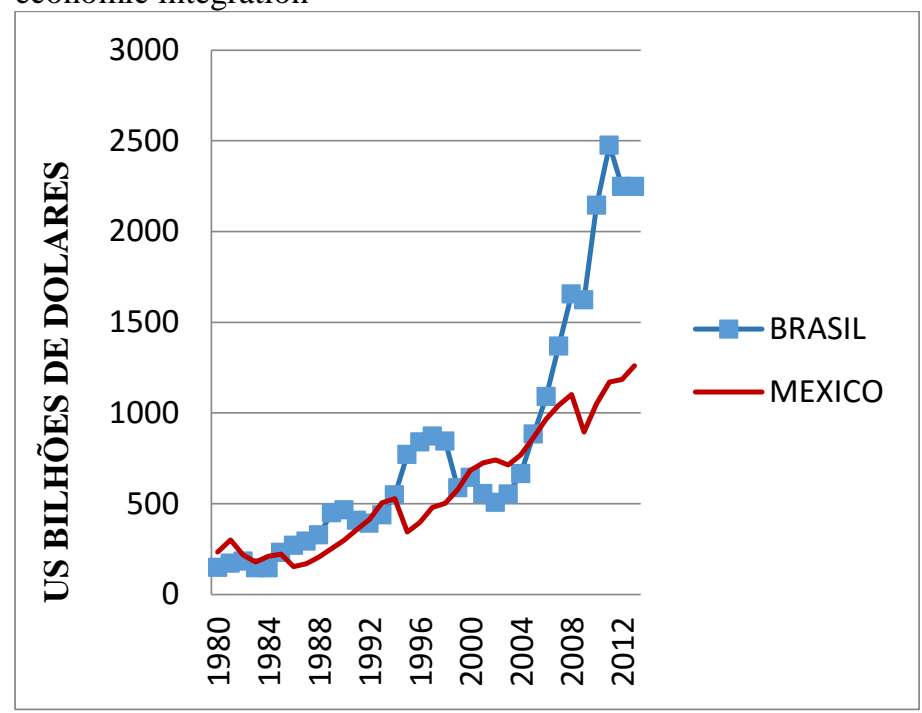

As a first Cointegration Test stage of Engle - Granger (1987 ), a linear regression between the two variables (GDP of Brazil and Mexico) and was generated Figure 5 was adjusted , which shows the behavior of the residues of regression, informally, plays with the distance between sets over the years analyzed .

Figure 5 - Waste of Cointegration Test Regression GDPs of Brazil and Mexico

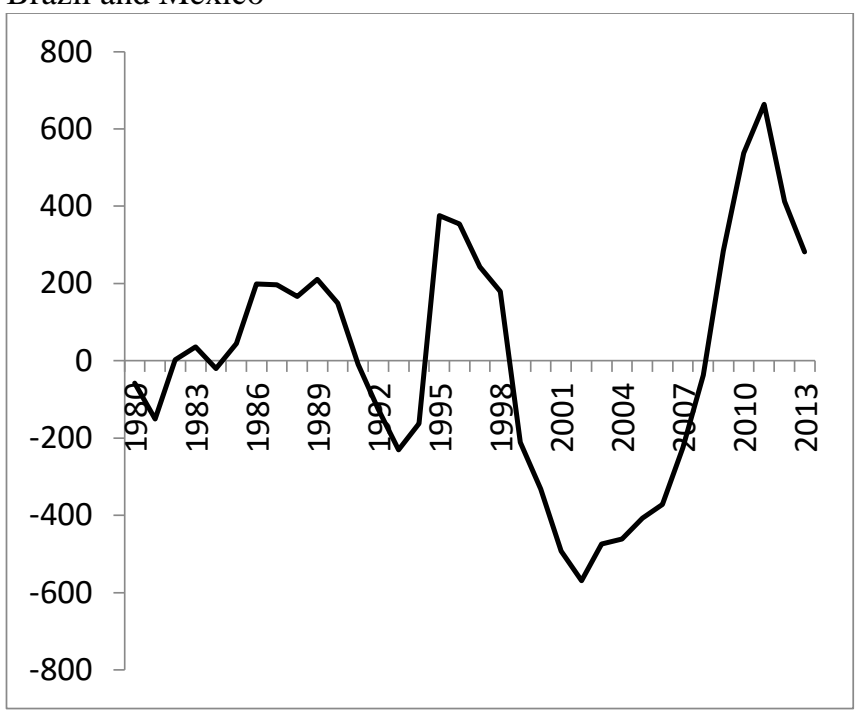

Source: Prepared by the authors, based on secondary data.

Although the dispersion of the number of waste proves increasing, over time, which may be a result of the increase in GDP size itself of the two countries over the years, visual inspection of the latter figure suggests that there is stationarity in waste and then cointegration of the original series, which weakens the possibility of spurious regression between the two variables.

To mitigate the effect of increasing the range of variables, the analysis procedure of repeated-series, but now, in their natural logarithms, which allows even the interpretation of the results in terms of elasticity relationship between the GDPs of two countries.

Figure 6 shows the behavior of two series over time, but transformed into logarithms.

Source: Prepared by the authors, based on secondary data. 
Figure 6 - GDP Brazil and Mexico in natural logarithms, before and after the economic integration

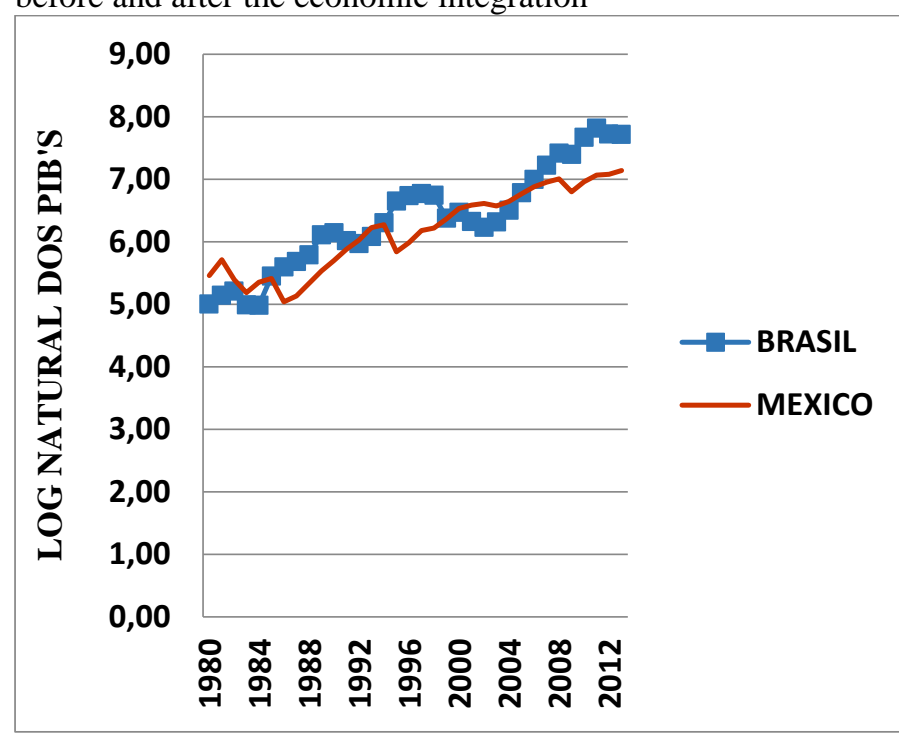

Source: Prepared by the authors, based on secondary data.

With this version transformed the variables are the strongest evidence in favor of cointegration hypothesis of the series, which is further reinforced with the also visual inspection, in Figure 7, the new waste obtained from the new regression of cointegration test Engle-Granger to the logarithm of the series.

Figure 7 - Residues from Cointegration Test Regression GDPs of Brazil and Mexico

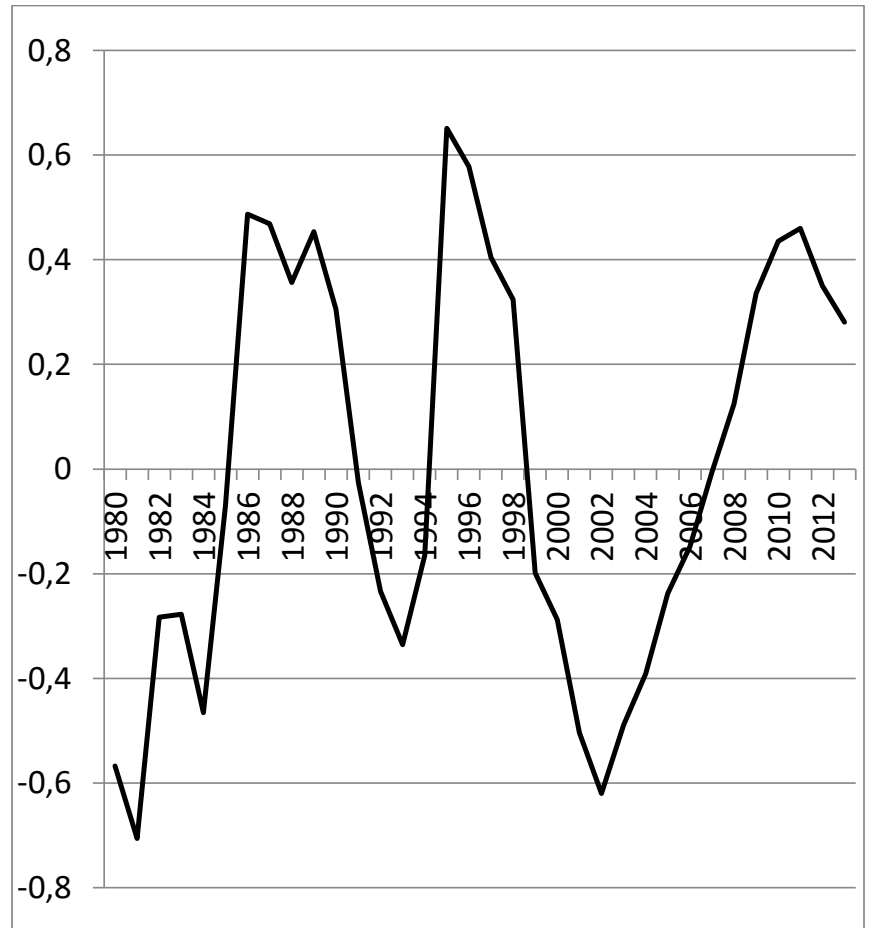

Source: Prepared by the authors, based on secondary data.
Understood then how small the risk of spurious regression of integrated series of order 1 it is possible to move to the interpretation of results. It was introduced in the model a variable Dummy for the eventual change test in the relationship of two variables, after economic integration, and the estimates were those contained in Table 1.

Table 1 - Regression to Break Test with the logarithm of the GDP's of Brazil and Mexico

\begin{tabular}{lr}
\multicolumn{2}{l}{ SUMMARY of RESULTS } \\
\hline \multicolumn{2}{c}{ Statistics of regression } \\
\hline R multiple & 0,9984 \\
R square & 0,9967 \\
Adjusted R square & 0,9630 \\
Standard error & 0,3920 \\
Observations & 34 \\
\hline
\end{tabular}

\begin{tabular}{|c|c|c|c|c|c|c|}
\hline & gl & $S Q$ & $M Q$ & $F$ & $F$ of signification & \\
\hline Regression & 4 & 1393,5349 & 348,3837 & 2267,4873 & 0,0000 & \\
\hline Residual & 30 & 4,6093 & 0,1536 & & & \\
\hline \multirow[t]{2}{*}{$\underline{\text { Total }}$} & 34 & 1398,1442 & & & & \\
\hline & Coefficients & Standard error & P-value & Start t & $95 \%$ less than 9 & $95 \%$ higher than \\
\hline BEFORE & 6,4524 & 3,5533 & 1,8159 & 0,0794 & $-0,8044$ & 13,7092 \\
\hline MEXICO_BEFORE & $-0,1977$ & 0,6634 & $-0,2980$ & 0,7678 & $-1,5525$ & 1,1571 \\
\hline AFTER & $-0,0959$ & 1,2245 & $-0,0783$ & 0,9381 & $-2,5966$ & 2,4048 \\
\hline MEXICO_AFTER & 1,0536 & 0,1877 & 5,6135 & 0,0000 & 0,6703 & 1,4369 \\
\hline
\end{tabular}

Source: Prepared by the authors, based on secondary data.

The analysis of the estimates of the $p$ values suggest the following interpretation:

i. The estimate of $76.78 \%$ for the null hypothesis on the coefficient of the variable "MÉXICO_BEFORE" does not allow the rejection of the hypothesis that there was no relationship between the GDPs of the two countries before the economic integration;

ii. On the other hand, from $0.00 \%$ the estimate for the null hypothesis on the coefficient of the variable "MÉXICO_AFTER" allows the rejection of the null hypothesis that there was no relationship between the two countries PIBS after economic integration, i.e. accepted the hypothesis that, after economic integration, the GDPs of Brazil and Mexico kept relation to each other.

Once verified rejection of the hypothesis that there was no relationship between the GDPs of the two countries, through analysis with the variable "MÉXICO_AFTER", it becomes unnecessary to analysis with the variable relative to GDP in Brazil.

Revista de Negócios, v. 20, n. 3, p. 41-50, July, 2015. 
In addition, it could be applied to a structural break test as proposed by Chow (1960). However, this test consists of splitting into two sub-periods in order to estimate parameters that each of these sub-periods, subjected to a statistical $F$ test the equality of two sets of estimated parameters. It happens that the selected sample, four data series included in the periods before and after the economic integration of the two countries is not very extensive and the application of the Chow test (1960) become restricted to a priori choice of date / time of structural break and, therefore, would be unnecessary to apply this test.

\section{Conclusion}

This study sought to understand the factors that lead countries to realize economic integration and the influence of internationalization in GDP, specifically, Brazil and Mexico.

Using the cointegration test, we sought to determine whether economic integration could boost GDP growth.

Through the graphical analysis of the two series and the waste of the regressions for Cointegration tests of Engle-Granger of variables, we can accept the hypothesis that, from economic integration, the economies of Brazil and Mexico had a direct correlation in their GDP's.

This positive assessment of economic integration is sufficient to register their importance in the economic context of both countries, and dispenses a further discussion on the theoretical reflections of the study.

Therefore, it is concluded that both Brazil's GDP as Mexico grew after the integration of each country to their economic blocks (Mercosur and NAFTA).

Thus, when registering the important effect of economic integration in the Brazilian and Mexican GDP growth was both one as the other, responds to the problem of research and reaches to the overall objective of the same.

As an extension of this study suggest possibilities are the following:

i. Carry out the same test on a series of more extensive data, i.e., a sample that includes a larger number of years the integration of two countries in the respective blocks (including the structural Chow break test);

ii. For this broader range of data, apply the Durbin-Watson test on cointegration regression in order to achieve greater certainty about the degree of cointegration between the variables proposed;

iii. Apply the correction mechanism EngleGranger errors (1987) in order to obtain the equilibrium relationship between short series and long term.

\section{References}

BALASSA, B. Teoria da Integração Econômica. Lisboa: Clássica Editora, 1964.

BIELSCHOWSKY, R. (org.). Cinquenta Anos de Pensamento na CEPAL. Rio de Janeiro: Ed. Record, 2000.

BUENO, R. de L. da S. Econometria de Séries Temporais. São Paulo: Cengage Learning, 2008.

CARBAUGH, R. Economia Internacional. São Paulo: Editora Pioneira Thomson Learning, 2004.

CHOW, G. C. Tests of Equality between Sets of Coefficients in Two Linear Regressions. Econometrica, vol. 28, $n^{o}$ 3, p. 591-605, july 1960.

CORRAL, M. I. M. La Integración Económica. Información Comercial Española - ICE: Revista de Economía, $n^{o}$ 858, 2011, p. 119132. Disponivel em http://www.revistasice.com/CachePDF/ICE _858_119132_660DOF2D853D0505C9F365F4B9C F7C45.pdf, acesso em 31/03/2016.

ENGLE, R.F.; GRANGER, C.W.J. Cointegration and error correction: representation, estimation, and testing. Econometrica, v 35, n 1, p. 251-276, 1987.

EROSA, A.; KORESHKOVA, T. A. RESTUCCIA, D. How important is human capital? A qualitative theory assessment of world income inequity. The Review of Economics Studies, v. 77, $n^{\circ}$ 4, p. 1421-1449, 2010.

GREMAUD, A. P.; VASCONCELLOS, M. A. S. de; TONETO Jr., R. Economia Brasileira Contemporânea. $\sigma^{a}$ ed. São Paulo: Atlas, 2005.

GUJARATI, D. Econometria Básica. $3^{a}$ ed. Rio de Janeiro: Elsevier, 2006.

HALL, R. E.; JONES, C. I. Why do some countries produce so much more output per worker than others? The quarterly journal of economics, Oxford University Press, v. 114, n.1, p 83-116, 1999. 
KRUGMAN, P. R.; OBSTFELD, M. Economia Internacional: Teoria e Política. $\sigma^{a}$ ed. São Paulo: Pearson Addison Wesley, 2005.

$M A D D A L A, G . S$. Introdução à Econometria. $3^{a}$ ed. São Paulo: LTC Editora, 2003.

MANKIW, N. G.; ROMER D.; WIEL, D. N. A contribution to the empirics of economic growth. The quarterly journal of economics, Oxford University Press, v. 107, n. 2, p 407437, 1992.

MANUELLI, R. E.; SHESHADRI, A. Human capital and the wealth of nation. University of Wisconsin-Madison, 2010. Disponivel em http://www.econ.wisc.edu/ aseshadr/workin g_pdf/humancapital.pdf, acesso em 10/06/2015.

RICHARDSON, R. J. et al. Pesquisa social: métodos e técnicas. São Paulo: Atlas, 1999.

SANTOS, M. O México como Aliado dos EUA no Projeto de Integração das Américas, Revista Brasileira de Politica Internacional, 50 (2):146-161, 2007.

SARQUIS, S. J. B. Crescimento internacional e crescimento econômico no Brasil. Brasília: Fundação Alexandre Gusmão, 2011.

SOLOW, R. M. A Contribution to the theory of economic growth. The quarterly journal of economics, Oxford University Press, v.70, n.1, p 65-94, 1956.

. Technical change and the aggregate production function. The review of Economics and Statistics, JSTOR, v.39, n.3, p. 312-320, 1957.

VEIGA, P. da M. Política Comercial no Brasil: características, condicionantes domésticos e policy-making. In: JANK, M. S.; SILBER, S. D. Politicas Comerciais Comparadas: desempenho e modelos organizacionais. São Paulo: Singular, p. 71-162, 2007.

Revista de Negócios, v. 20, n. 3, p. 41-50, July, 2015. 